\title{
Gorazd: An Old Church Slavonic Digital Hub and the Romanian Slavonic studies
}

\author{
Vladislav Knoll ${ }^{\oplus \Delta \star}$ \\ Institute of Slavonic Studies, Czech Academy of Sciences, Valentinská 1, 11000 Prague, Czech Republic
}

\begin{abstract}
Article info
History:

Accepted October 5, 2021

Key words:

old Church Slavonic

Romanian Slavonic

digital lexicography

historical lexicography

old Romanian

Slavonic loanwords
\end{abstract}

Received September 13, 2021

Published December 12, 2021

\begin{abstract}
The aim of this paper is to present the utility of the Gorazd: An Old Church Digital Hub for scholars working with Old Romanian and Slavonic texts written on the territory of today's Romania. The Gorazd Project was realized during the years 2016-2020 and it includes an Old Church Slavonic Card Index and three Old Church Slavonic lexical databases, among which the largest one is represented by the digitized and updated version of the monumental Lexicon lingue paleoslovenice (vol. I-IV, 1958-1997) composed by the Institute of Slavonic Studies of the Czech Academy of Sciences. As the Gorazd Project uses English as meta-language, its application is not limited to narrowly specialized Slavic philologists, but it is also open for scholars of neighbouring fields. The dictionaries within the Gorazd Digital Hub can serve as a reference tool not just for the oldest attested Slavonic vocabulary and its semantics, but also for the biblical concordance of the Slavonic oldest Bible redaction and the oldest attested Old Church Slavonic morphological forms.
\end{abstract}

\section{Introduction: the very basics of Gorazd}

Gorazd: An Old Church Slavonic Digital Hub (gorazd.org) is a project that was accomplished within the NAKI II programme of the Ministry of Culture of the Czech Republic during the years 2016-2020 by the Institute of Slavonic Studies of the Czech Academy of Sciences. As the name of the project signalizes, its main aim has been to encompass the vocabulary of the Old Church Slavonic (henceforth ocs) language. ocs can be perceived as the first phase of the development of the Church Slavonic (cs) language (cf. Mathiesen, 1984, p. 46-47; Tolstoj, 1988, p. 47; Mareš, 2000, p. 542-543), playing the role of a supraconfessional classical language of the Central, Eastern and Southeastern Europe, whose most persevering function has been the liturgical one. Due to this fact and because of the specific selection of excerpted texts, the Gorazd Digital Hub can serve as a valid tool for scholars or students dealing with the Old Romanian texts or Slavonic texts composed on the territory of today's Romania. Before we specify the manner of how to use Gorazd for these purposes, we will shortly characterize the contents of the Gorazd Digital Hub and the tools and databases it offers. We will not go into much detail regarding the history and background of the Gorazd Project and its developing methods as this can be read in other sources both in English and Romanian (Pilát et al., 2018; Knoll, 2019a,b).

The Gorazd Project has had two types of outcomes: the lexicographic and the software ones. The lexicographic part of the project comprised the digitization of three Old Church Slavonic dictionaries and an Old Church Slavonic Card Index created by several generations of the members of the Institute of Slavonic Studies. The Old Church Slavonic Card Index is based on the largest one of four interrelated card indices, the creation of which started already in 1943. Its digitized version includes 712813 card slips, covering all forms attested in the excerpted texts. The standardized shape of the card slips became the model for the creation of other similar projects. The largest of the dictionaries, the Old Church Slavonic Dictionary (OCSD), is a digitized version of the Lexicon lingua palaslovenica (LLP) published between

^Email address:knoll@slu.cas.cz. 
1958 and 1997 in 52 fascicles and 4 volumes with incorporated Supplements to the Volume I (Addenda), the composition of which started in 2008. Thus, the digitized version of the lemmas starting with the letters $\mathbf{a}-\mathbf{n}$ has been completely revised and new excerpted texts were added. Besides the thoroughly revised volume one, the digital OCSD differs from the original LLP also by meta-language. While LLP used Latin, OCSD offers all linguistic and factual explanations in English. The English language became also one of the languages of the equivalents, besides German, Russian, Czech, Latin, respectively Greek and Old High German (languages of the model texts) that were already included into LLP. Today, OCSD counts 18944 entries.

The second included lexicographic work is the Dictionary of the Oldest Old Church Slavonic Manuscripts (DOOCSM) counting 11563 entries. It represents a revised and enlarged version of the Staroslavjanskijslovar' (po rukopisjam X-XI vekov), published originally in Moscow in 1994 as a fruit of cooperation between Czech and Russian scholars. The third and the youngest lexicographic database is the Greek Old Church Slavonic Index counting so far 2542 entries. It represents the volume one (IVGP, letters $\alpha-$ $\gamma$, composed 2004-2014) of a tool addressed to the text critics and translatology, eventually theological studies.

The second, but not minor part of the project was the software one. This part of the project had two main goals: (a) creation of tools for digitization of historical multilingual (multi-scriptural) dictionaries; (b) creation of the presentation interface(s) for the digital lexicographic works.

The aim of the first task was the proposal of such a software that would maximally automatize the process of digitization and allow an easy correction or composition of a digital dictionary by a person with minimal IT knowledge. The result of the development consists of three tools that are currently available free on our website.

Gorazd Generator permits an automatic generation of dictionary entries based on OCR (ALTO/ $\mathrm{XML}$ ) or TXT files ${ }^{1}$. Within the project, the optical recognition was done within the ABBYY Recognition Server. The scripts that were recognized were Latin (Czech, German, Latin, Old High German), polytonic Greek, Cyrillic Civil script (Modern Russian) and old (Uncial) Cyrillic (ocs). In order to get better results in the recognition of ocs, the Dictionary for Old Church Slavonic Optical Character Recognition was created. In addition, this tool is now available for any interested person ${ }^{2}$. Based on the predefined criteria, the Gorazd Generator splits the text to dictionary entries and sets the basic XML structure of the entry.

The Gorazd Editor enables the correction and editing of the outcomes of OCR by a person without any clue about XML. This tool is based on the open-source software INVENIO $^{3}$ and it permits an easy comparison of the scanned original of the lexicographic work with the outcome of the Gorazd Generator. The updating of the XML structure is done intuitively using colours and keyboard shortcuts. The composition of new contents is as easy as using MS Word ${ }^{4}$.

The last of these tools is the Gorazd Export, which permits an easy pre-print preparation of the whole database elaborated by the previously mentioned applications. Its outcome is an HTML, DOC or RTF file ${ }^{5}$. We are sure that this software set is perfectly fit for processing the lexicographic or encyclopædic works of Old Romanian or Romanian Slavonic, thus the works combining Latin, Cyrillic, eventually Greek script.

The second set of software tools developed in the framework of the Gorazd Project are the presentation interfaces. The interface called Gulliver ${ }^{6}$ includes the three mentioned dictionaries that are discoverable using advanced searching tools. The virtual keyboard and searching support are, of course, available. The

\footnotetext{
${ }^{1}$ More details and the installation package are available at gorazd.org.

${ }^{2}$ The tool with further info and a user manual are available at gorazd.org.

${ }^{3}$ Developed by CERN (i.e., European Organization for Nuclear Research); cf. inveniosoftware.org.

${ }^{4}$ More details and the installation package are available at gorazd.org.

${ }^{5}$ More details and the installation package are available at gorazd.org.

${ }^{6}$ Direct access at gorazd.org.
} 
user can search not only the ocs lexemes, but the dictionary also enables the search of ocs equivalents in modern (English, German, Russian, Czech) and classical (Latin, Greek) languages. The user can also predefine specific searching criteria as e.g. grammatical categories or group of texts. The outcomes of the searching might be used for statistical purposes, permitting e.g. to get a complete list of lexemes belonging to a concrete declension within one (or more) concrete ocs text $(s)$. The OCSD and the Greek-OCs Index are interlinked. The OCSD is further interlinked with the complete Old Church Slavonic Card Index. Thus, each OCSD entry enables the consultation of the total of all attested forms of a concrete lexical unit. Besides the direct access through the Gulliver interface, the ocs Card Index can be easily consulted also in a separate interface, Archive of Old Church Slavonic Card Index allowing a user-friendly virtual leafing through the whole Card Index ${ }^{7}$.

For the support of the scholars dealing with (Old) Church Slavonic texts and language, we also prepared several minor tools. These include:

- the Cyrillic and Glagolitic Numerals' Converter ${ }^{8}$,

- an online list of links to digital collections of Church Slavonic manuscripts and early prints ${ }^{9}$,

- an online list of links to digitized or digital Slavic historical dictionaries (covering mainly the Medieval and Early Modern Age varieties) ${ }^{10}$.

The last two tools also include the sources linked to the Romanian Speaking Lands. All the mentioned outcomes and databases are accessible from the Gorazd.org website (gorazd.org), which possesses, equally as the interfaces, three fully equivalent language versions: English, Russian and Czech. A by-product of the Gorazd Project is its Facebook profile (facebook.com), which publishes materials for popularization of (Old) Church Slavonic, Slavic philology and the research of old languages in general.

\section{Spelling}

In the second part of my paper, I will present Gorazd as a tool for scholars dealing with Old Romanian or Slavonic texts from today's Romania. This will serve us as a perspective to explain the contents of the Gorazd Digital Hub. When using the databases, one should be aware about the spelling differences between our database and the examined text. The spelling norm used by OcsD generally corresponds to the norm used by usual manuals or dictionaries of Old Church Slavonic. Nevertheless, it has some specifics that should be discussed, most clearly by comparing it with other commonly used sources ${ }^{11}$ :

\begin{tabular}{|c|c|c|c|c|}
\hline Common Slavic $^{12}$ or Greek & OCSD & $\mathbf{S B R}^{13}$ & $\begin{array}{l}\text { Miklosich } \\
(1862-1865)^{14}\end{array}$ & $\begin{array}{l}\text { Olteanu et al. } \\
(\mathbf{1 9 7 5})^{15}\end{array}$ \\
\hline *(j)aviti 'to appear' & авити & Іавити & гавити & гавити \\
\hline *(j)eterŭ 'someone' & ETTE९' & ЮTE९һ & ютерђ & 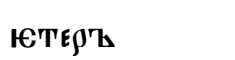 \\
\hline *dzèlo 'very' & stato & $3 \$ 10$ & $3 \pitchfork A 0$ & $\operatorname{stato}$ \\
\hline *bol'ii 'bigger' & Боиิии & БойLи & Болий & Болии \\
\hline
\end{tabular}

${ }^{7}$ Direct access at gorazd.org.

${ }^{8}$ Direct access at prevodnik.gorazd.org.

${ }^{9}$ Direct access at gorazd.org.

${ }^{10}$ Direct access at gorazd.org.

${ }^{11}$ The spelling norm of OCSD is explained in LLP 1, LIII-LV (online, so far in Latin).

${ }^{12}$ Based on ESJS replacing $\mathbf{k}>\check{i}$ and $\mathbf{~} \mathbf{b}>\check{u}$.

${ }^{13} \mathrm{SBR}$ is available online within the lexicographic database HistDict (bistdict.uni-sofia.bg). Its spelling serves as a norm of further dictionaries included into HistDict. This database deals also with Middle Church Slavonic sources, which makes it a crucial tool for the study of Slavonic texts from Romania.

${ }^{14}$ Online consultable on monumentaserbica.branatomic.com. It is traditionally maybe the most popular Church Slavonic dictionary used in the Slavonic studies (due to its availability) in Romania and it also includes some Slavonic texts from Romanian (Argeş inscriptions). Nevertheless, it lacks a clearly defined excerption base, so it should be used with caution.

${ }^{15}$ The best Old Church Slavonic manual available in Romanian (and actually one of the best ocs manuals in general) with a detailed overview of the language features of the Slavonic varieties used in Romania, a reference point for later works. 


\begin{tabular}{|c|c|c|c|c|}
\hline *kon'ǐ'horse' & 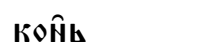 & 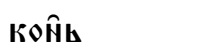 & KONG & KON'b \\
\hline *rybar'î'fisher' & 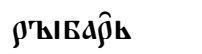 & $\rho^{\prime} \mathbf{z} \mathbf{L} \mathbf{\alpha} \hat{\jmath} \mathbf{k}$ & $\rho$ & $\rho$ \\
\hline *žrirtva 'sacrifice' & 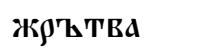 & 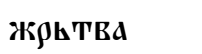 & 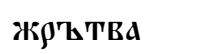 & 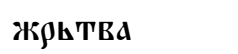 \\
\hline *tǔlkQ 'I knock' & ТАһкж & ТАьк及 & ТАҚкж & ТАҚкж \\
\hline *krǐstijanŭ 'Christian' & көцстнанқ & 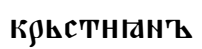 & көқститанқ & 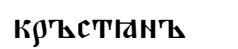 \\
\hline *slizza 'tear' & cAb3a & cAh3a & c $\mathbf{A}^{\prime} \mathbf{b} 3 \mathrm{Ad}$ & cAk3d (cA'b3a) \\
\hline 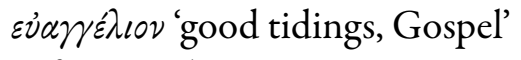 & ЕВАNГ̃ЕАНЮ & ЕВАNГ̃ЕАLЮ & ЮВАКГЕАНЮ & ЮВАКГЕАНЮ \\
\hline$\psi \alpha \lambda \mu o ́ s$ 'psalm' & ПсдА'Қдһ & ПсАА'ҚА'Қ & భая'Қдақ & 0 \\
\hline
\end{tabular}

Overall, the OCSD provides a slightly different balance between the etymology and the forms preserved in the ocs canonical manuscripts than the other handbooks. In any case, the search support helps the user to find the desired word even if he is not fully aware of the spelling norm as each entry contains also the spelling variants of the excerpted texts. It should be added that there are few differences that can be observed between OCSD and the DOOCSM, which shows a similar treatment of the liquid + jer clusters as SBR (thus жрьтва, but тл'ъкж).

The ocs spelling significantly differs from the spelling the Romanian Slavonic scholar is working with. The bookish texts of the Cultural Slavonism proprio sensu $\left(14^{\text {th }} \text {-early } 18^{\text {th }} \text { century }\right)^{16}$ were written in the Middle Church Slavonic varieties, since the second third of the $17^{\text {th }}$ century also in the Early New Church Slavonic ${ }^{17}$. The common Middle cs variety used in the Romanian Speaking Lands was the Trinovitan (Tărnovo) norm, which was the most conservative among the Middle cs varieties and it provided the spelling base for the Old Romanian writing. Moreover, the Resavian norm was also used in Wallachia. The numerous spelling variations found in the texts from Wallachia, Moldavia, eventually Transylvania are due to the different base of local chancellery languages, different languages in contact and a different liturgical pronunciation. Let us make a small comparison:

\begin{tabular}{|c|c|c|c|c|c|}
\hline OCS & $\begin{array}{l}\text { Trinovitan } \\
\text { CS }^{18}\end{array}$ & $\begin{array}{l}\text { Resavian } \\
\text { CS }\end{array}$ & $\begin{array}{l}\text { Wallachian } \\
\text { chancellery }^{19}\end{array}$ & $\begin{array}{l}\text { Moldavian } \\
\text { chancellery }^{20}\end{array}$ & $\begin{array}{l}\text { Early New } \\
\text { Cs }^{21}\end{array}$ \\
\hline $\begin{array}{l}\text { Тындымица } \\
\text { ‘jail' }\end{array}$ & ТЕННИЦА & ТАдница & $\begin{array}{l}\text { ТАНАИЦА/ } \\
\text { ТЕАнИЦА } \\
\text { (ТАНКИЦА) }\end{array}$ & \multicolumn{2}{|c|}{ ТЕАNИЦА } \\
\hline BhCE 'all' & B'LCE & B'LCE/BLCE & B'LCE/BLCE/CBE & B'ZCE/OYCE & BCE/B'LCE/BLCE \\
\hline $\begin{array}{l}\text { нжка } \\
\text { 'suffering' }\end{array}$ & нжка & ноука & \multicolumn{2}{|c|}{ нУКА/НҺКА/Нжка } & ноука (нжка) \\
\hline $\begin{array}{l}\text { панать' } \\
\text { 'memory' }\end{array}$ & ПАНАТ' & ПАНЕТТ & 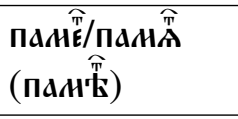 & 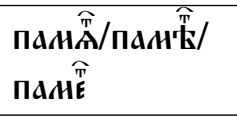 & ПАНАTИ \\
\hline $\begin{array}{l}\text { 'мзик'ы } \\
\text { 'language' }\end{array}$ & $\begin{array}{l}\text { Азыкы } \\
\text { (жзыки) }\end{array}$ & ЄЗыкй & E. & \multicolumn{2}{|c|}{ A3 $3 \mathbf{b}^{\widehat{\kappa}} / / 23 \mathbf{k}^{\widehat{K}}$} \\
\hline $\begin{array}{l}\text { ЖАжАд } \\
\text { 'thirst' }\end{array}$ & жжжАd & ЖЕЖАА & $\begin{array}{l}\text { ЖЕЖЖАА } \\
\text { (Ж'ъЖАДа) }\end{array}$ & \multicolumn{2}{|c|}{ ЖАЖААаЖЖАЖАА } \\
\hline
\end{tabular}

\footnotetext{
${ }^{16}$ It can be defined as the period between the establishment of the Romanian States and the final replacement of the Church Slavonic by the Romanian in the role of a liturgical language.

${ }^{17}$ Mainly in Wallachia, where the prints since 1635 were no more done in Middle Church Slavonic (except the Pentecostarion of 1649) and with the reservation that the spelling of the Euchologion of 1635 had a transitional character. In Moldavia, the transition towards the New Cs was slower as both the local Middle cs variety and the Romanian language had there a stronger position in that time.

${ }^{18}$ Cf. the dictionary within Bogdan's edition (1922) of the Chronicle by Constantine Manasses that is sometimes used as a dictionary of the Church Slavonic used in Romania.

${ }^{19}$ Cf. Djamo-Diaconiță (1971, p. 21-91).

${ }^{20}$ Cf. the variation in SSUM representing actually a dictionary of the Moldavian chancellery documents of the $14^{\text {th }}-15^{\text {th }}$ centuries.

${ }^{21}$ Cf. the variation in Berynda (1627).
} 


\begin{tabular}{|c|c|c|c|c|c|}
\hline \multirow{2}{*}{ 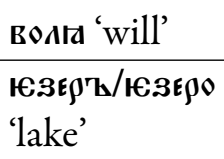 } & \multirow{2}{*}{$\frac{\text { вол' }}{\text { EsE } \rho \mathcal{A}}$} & \multirow{2}{*}{ 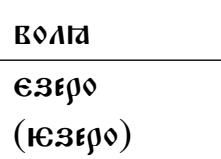 } & \multirow{2}{*}{ 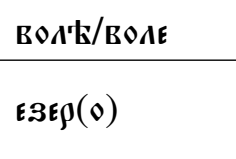 } & \multicolumn{2}{|c|}{ BOAA } \\
\hline & & & & $W 3 E \rho \odot / \epsilon 3 E \rho(\vartheta)$ & E.3ESO \\
\hline $\begin{array}{l}\text { А०Б'И'Ти 'to } \\
\text { reach' }\end{array}$ & \multicolumn{2}{|c|}{ АоБытти 'to get, to conquer' } & $\begin{array}{l}\text { АоБитти 'to } \\
\text { get' }\end{array}$ & $\begin{array}{l}\text { АОБыти } \\
\text { (АоБити) 'to } \\
\text { get, to } \\
\text { conquer' }\end{array}$ & АОБыти \\
\hline 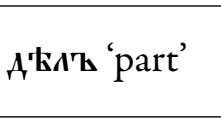 & $\mathrm{A} \mathrm{thAb}$ & A'tAs & 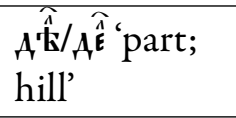 & $\begin{array}{l}A \hat{\hat{n}} / A \hat{\hat{k}} / A \hat{\hat{n}} / A \widehat{\hat{E}} \\
\text { hill' }\end{array}$ & $A^{\prime} \mathbf{k} \boldsymbol{A}^{\top} \mathbf{\mathbf { b }}$ 'part' \\
\hline 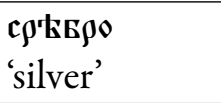 & $\mathfrak{c} \rho \mathbf{k E} \rho \mathcal{0}$ & $\begin{array}{l}\text { с } \rho \text { ББ } \rho \mathcal{O} \\
(\mathfrak{c} \rho \in \mathrm{E} \rho \mathcal{O})\end{array}$ & $\mathfrak{c} \rho \in \mathbf{E} \rho \mathcal{} \rho / \mathfrak{c} \rho \mathrm{K}$ Б $\rho \mathcal{O}$ & $\mathfrak{c} \rho \in \bar{E} \rho \mathcal{O} / \mathfrak{c} \in \rho \in \mathrm{E} \rho \mathcal{O}$ & $\mathfrak{c} \rho \in \mathbf{E} \rho \mathcal{O}$ \\
\hline $\begin{array}{l}\text { т } \rho \mathbf{s} \mathbf{\Gamma} \mathbf{b} \\
\text { 'market' }\end{array}$ & $\mathbf{T} \rho \mathbf{h} \mathbf{h}$ & \multicolumn{2}{|c|}{ 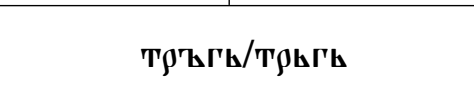 } & \multicolumn{2}{|c|}{ 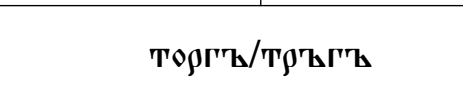 } \\
\hline в $\mathbf{g}^{\prime} \mathbf{z} \chi^{\prime \mathbf{z}}$ 'hill' & $\mathbf{B} \rho \mathbf{h} \chi^{\prime} \mathbf{k}$ & \multicolumn{2}{|c|}{ 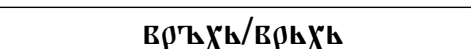 } & \multicolumn{2}{|c|}{ 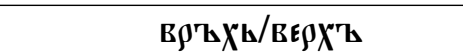 } \\
\hline
\end{tabular}

The Middle and New CS are missing $\mathbf{i} \mathbf{m}, \mathbf{x}$ and $\boldsymbol{\iota}$ (the latter except for Resavian). The jers in weak positions are mostly omitted (except for some morphological borders and final positions), the jers in strong positions are often submitted to vocalizations, while their quality is rather depending on the position within the stress unit or they are random. The positions of ${ }_{e}^{*},{ }^{*},{ }^{*} e,{ }^{*} j a$ and ${ }^{*} y$ are the most variable ones depending on different spelling traditions and pronunciation. When comparing the vocabulary of Old Romanian texts ${ }^{22}$ with ocs, one must also count e.g. with the occurrence of the following traits:

- treatment of jers corresponds to the Trinovitan Cs, e.g. $29^{\mathrm{v}}$ телниицд - осs тьмьница 'jail', $90^{\mathrm{v}}$ сфи́токи - осs с'ъвит'ък'ъ 'scroll, book';

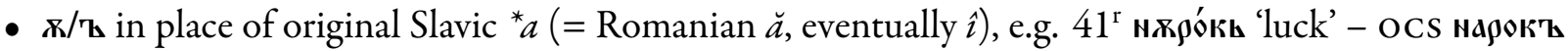

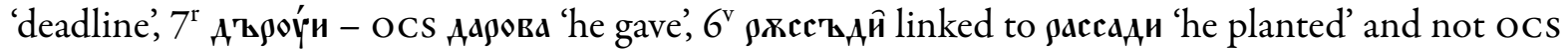

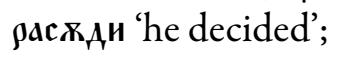

- $\mathbf{t}$ instead of original Slavic ${ }^{*} e$ (= Romanian $e a$ or a product of the variation $\mathbf{t} / \mathfrak{\varepsilon}$ in Wallachian texts),

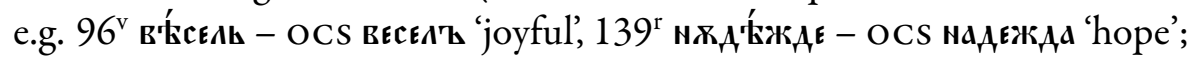

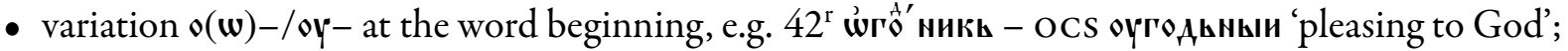

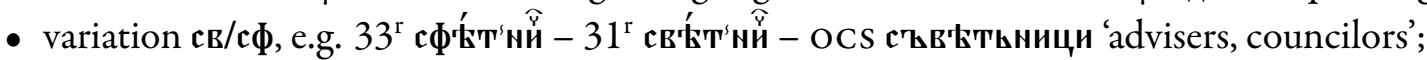

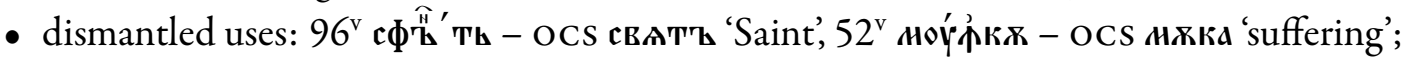

- further adaptations especially among the earlier loanwords (from Slavic vernaculars), e.g. $15^{\mathrm{r}}$ noýperïв

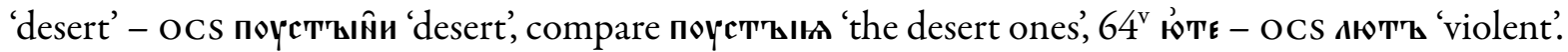

\section{Gorazd as the reference point for Old Romanian and Slavonic texts from Romania}

In this chapter, we will mention some examples of the use of the Gorazd Digital Hub as the reference point for Old Romanian, respectively Romanian Slavonic Studies. Of course, the most expected use of Gorazd is the consultation of the vocabulary. In this regard, we have to define the excerption basis of OCSD and its consequences for the Romanian Slavonic scholars. The texts incorporated into OCSD are of three types:

- Canonical ocs manuscripts (i.e. those written between the $9^{\text {th }}$ and $11^{\text {th }}$ centuries).

- Postcanonical manuscripts, i.e. later Church Slavonic copies (including the Croatian Glagolitic ones) of texts of presumably Cyrillo-Methodian origin.

- Czech Church Slavonic texts, i.e. those believed to be composed on the territory of today's Czech Republic in the $10^{\text {th }}-11^{\text {th }}$ centuries.

\footnotetext{
${ }^{22}$ Examples are taken from Moxa (1620).
} 
The Gorazd Digital Hub enables the limiting of the search just to one of these text groups or to all of them or to single texts. Each entry contains the list of texts containing the concerned lexical unit. This list enables to establish to which group of texts the lexeme belongs. Within almost each entry, there is a list of synonyms.

The vocabulary of the OCs canonical texts is the one that is largely shared with SBR and which is more completely recorded in the Doocsm (due to the inclusion of the later found canonical texts). From the perspective of the Romanian philology, it is worth repeating that the dialectal base of the Church Slavonic is similar to the Common Slavic dialect that was in contact with Common Romanian. Thus, this part of the dictionary contains the lexical units whose phonological state corresponds to the one preserved in

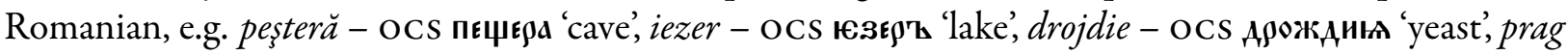
'threshold; entrance' - ocs nfar'z 'doorcase'. Moreover, we may find also the specific vocabulary common

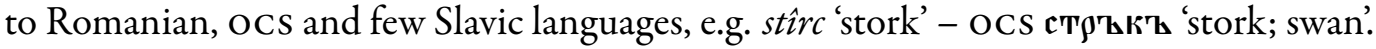

The inclusion of the second group of texts has the consequence that the OCSD can be actually used as a sort of biblical concordance. The excerpted ocs biblical books include the whole New Testament, the Psalter, as well as parts of the Old Testament comprising the Prophetologion, or the Old Testament Lectionary (most complete parts are taken from Genesis, Exodus, Book of Chronicles and Isaiah) and the books of Minor Prophets. Of course, the redaction attested in the Middle Church Slavonic and translated into Old Romanian does not fully correspond to the redaction excerpted in the OCSD, which should represent the first, Cyrillo-Methodian redaction. Still, the difference is small enough to keep the usefulness of the Gorazd Digital Hub for scholars working with Middle cs biblical texts. This can be illustrated by the comparison of Slavonic loanwords in Coresi' s Tetraevangelion (1561) with the lexemes attested at the same places in OCSD, e.g.

- $M t, 6,28: 11^{\mathrm{v}}$ көи́н8ль 'lily' - осs көин'ъ,

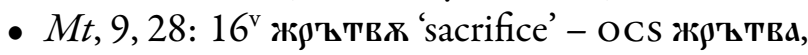

- $M t, 12,31: 24^{\mathrm{v}} \chi^{\circ}$ 교 'blasphemy' - ocs Xoysa,

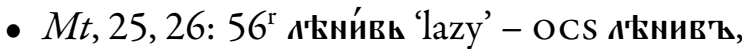

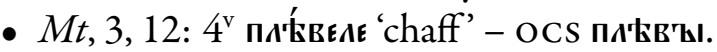

The Gorazd Digital Hub enables the limiting of the search just to the biblical books.

The third group of texts has less in common with the Romanian environment. Nevertheless, there are lexical units, partly shared with the East Slavic milieu, that correspond to some Old Romanian words, respectively words found in Slavonic texts from Romania, e.g.: sfită 'priest garment' - Czech Cs свита, dedină 'inherited property' - Czech CS A'Едина 'hereditary land' (thus also in Wallachian Slavonic in 1456, DRH B 1, p. 196).

The total of OCSD serves as the first reference point for the vocabulary of the Church Slavonic religious texts preserved in Romania. The search for a lexeme in OCSD allows setting the investigated lexical unit to the oldest attested lexical layer, eventually linking it to the biblical text (i.e. the model corpus of the Church Slavonic vocabulary). For further investigation of the Slavonic texts from Romania or Old Romanian texts one should use further lexicographical tools (see Knoll, 2021).

The texts excerpted into OCSD also contain some lexical units that are typical for Slavonic texts composed by Romanians or they are attested in (Old) Romanian, but show a different meaning. These lexemes can be divided into two main groups:

- Administrative terms used in the chancelleries of the Romanian Lands: e.g. осs ключарь 'keyholder' - Old Romanian/Romanian Slavonic clucer 'court official in charge of the provisioning of the court

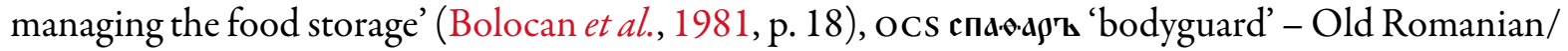
Romanian Slavonic spatăr 'commander of the cavalry' (p. 219), осs конис' ' 'prefect of a province' Old Romanian/Romanian Slavonic comis 'court official in charge of stables and horses' (p. 52), ocs отьчина 'homeland' - Old Romanian/Wallachian Slavonic ocină 'patrimony, heritage' (p. 161).

- Further lexemes corresponding to the borrowings in (Old) Romanian, e.g. осs кАопотты 'rattle, 
rumble' - Romanian clopot 'bell', ос глоун'ъ 'arrogance, disturbance' - Romanian glumă 'joke', ocs цАтта 'coin' - Romanian țintă 'nail; target', осл разБои 'crime, murder' - Romanian război 'battle, war', осs нарок'ъ 'deadline' - Romanian noroc 'luck'.

\section{Gorazd as the reference point for morphology}

Besides the vocabulary, Gorazd can be used as a reference tool for checking of the original form of a loanword in (Old) Romanian or a lexeme found in an original Slavonic text from today's Romania. There are certain rules of the transfer of Slavic declensions and conjugations into (Old) Romanian that may cause uncertainty in identifying the original form. Moreover, the Romanian authors of the Medieval and Early Modern Slavonic texts confused the gender and declension, especially in case the Slavic gender was different in Romanian equivalents or Romanian words with the same ending (cf. Djamo-Diaconiță, 1968, p. 241-249). See the following comparison of ocs and Romanian words.

- Romanian feminine nouns:

- Romanian $-\breve{a}$ :

* Slavic neuter: mită - OCs н'ытто 'bribe', pravilă - осs правило '(legal) regulation';

* Slavic masculine: slugă- ocs cnoyra 'servant';

* Slavic feminine: mreajă - ocs можжа 'net';

* Slavic feminine $i$-stem: poftă/pohtă - nox०ть 'lust'.

- Romanian -e:

* Slavic feminine $i$-stem: poveste - пов'Тсть 'story';

* Slavic feminine ja-stem: nădejde - надєж_a 'hope'.

- Romanian -ie:

* Slavic feminine $i$-stem: oblastie - овдасть 'region', zavistie - зависть 'envy';

* Slavic feminine ja-stem: utrenie - оүтрьна 'orthros, matins', milostenie - нилост'ы⿳ิи 'alms';

* Slavic neuter jo-stem: spăsenie - c'ъпасєнию 'salvation'.

- Verbs:

- Romanian -ui: a polzui 'to learn a lesson' - польsєвати 'to be useful; to have profit', $1^{\text {st }}$ singular

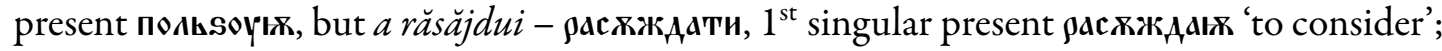

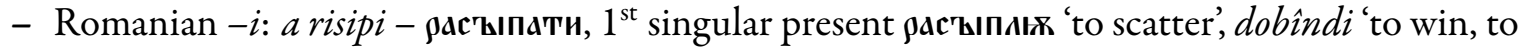

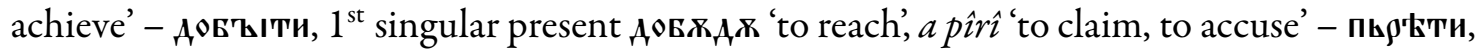

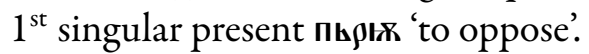

The dictionary and specifically the card index can also serve as a reference point for the valency. Thus, it enables us to compare if the valency attested in a Slavonic text written by a Romanian speaker corresponds to the valency of the oldest Slavonic texts. This approach can help to discover the syntactical Romanian impact in the Slavonic text. Of course, it has to be taken into consideration that the Balkan areal traits are common also to both Romanian and the neighbouring South Slavic languages. See e.g. FV (1592/1604):

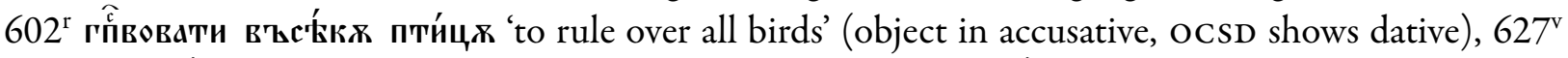
'̈Блада́т́т на̂ птиццани 'to rule over birds' (object with preposition нâ, OCSD shows instrumental without any preposition).

\section{Plans}

The finished digitization and the first phase of the revision of the dictionaries included into the Gorazd Digital Hub raise the question about the directions of the project continuation. One of the main goals for the near future should be the work on the consistency of the database that includes just a partial excerption 
of some texts, especially those found in 1975 in the Mount Sinai Monastery. The digital environment makes possible the completion of the dictionary per texts and no more per letters, which is definitely a more efficient way (more in Pilát, 2020). The inclusion of new texts can bring new data for the Romanian Slavonic linguistics, compare e.g. the lexical unit чевє in the Glagolitic Kozma's Healing (Rosenschon, 1994, p. 335), which is the closest (and the oldest attested) form related to the Romanian ştevie 'patience (plant)'. Besides the focus on the completion of the vocabulary attested in the canonical ocs manuscript, there also is an option to focus on the Czech cs database.

A question of further negotiations is an eventual inclusion of other digital lexicographic databases with shared (Old) Church Slavonic vocabulary. In particular, we mean the recently finished Etymological ocs Dictionary (ESJS) that draws upon the material base of LLP (Pilát, 2020, p. 80) and represents an indispensable tool for Slavists, Indoeuropeanists, but also Romanian etymologists. Theoretically, one can also imagine an integration of a dictionary dealing with Romanian Slavonic or (Old) Romanian vocabulary. As each Gorazd entry possesses its unique URL, the links to single entries of the Gorazd dictionaries can be simply added to digital dictionaries of various Slavonic varieties or Romanian ${ }^{23}$.

\section{Bibliography}

Addenda = Hauptová, Z., Konzal, V. \& Pilát, Š. (eds) (2016). Lexicon lingux paleoslovenica - Slovník jazyka staroslovènského, V. Addenda et corrigenda, Academia, Prague.

Berynda, P. (1627). Lexikon" slavenorosskij, i imen" Tl"kovanïe, Lavra Pečerskaja Kievskaja, Kiev.

Bogdan, I. (1922). Cronica lui Manasses. Traducere mediobulgară, Socec \& Co, București.

Bolocan et al. (1981). Dicționarul elementelor romănești din documente slavo-române 1374-1600, Editura ARSR, București. Cejtlin, R., Večerka, R. \& Bláhová, E. (1994). Staroslavjanskij slovar' (po rukopisjam X-XI vekov), Russkij jazyk, Moscow.

Coresi (1561). Tetraevanghel, Hanăș Beagner, Brașov.

Djamo-Diaconiță, L. (1968). Contribution à l'étude de l'influence roumaine sur la langue des documents slavo-roumains émis par la chancellerie valaque au XVe siècle, in "Revue roumaine de linguistique", 13 (3), p. 233-252.

Djamo-Diaconiță, L. (1971). Limba documentelor slavo-române emise în Ţara Românească în sec. XIV și XV, Editura Academiei, București.

DRH B 1 = Panaitescu, P.P. \& Mioc, D. (1966). Documenta Romanie Historica, B. Țara Românească, vol. I, Editura ARSR, București.

ESJS = Havlová, E., Janyšková, I. et al. (1989-2018). Etymologický slovnik jazyka staroslověnskébo, seš. 1-19, Academia, Prague / Tribun EU, Brno.

FV $=$ [Flower of Virtues $]$ (1592/1604), in Biblioteca Academiei Române, ms. rom. 4620, 1592-1604, ff. 457-627 .

IVGP = Bláhová, E. et al. (2008-2014). Řecko-staroslovènský index - Index verborum greco-paleoslovenicus, fasc. 1-8, vol. I., Euroslavica, Prague.

Knoll, V. (2019a). Gorazd: An Old Church Slavonic Digital Hub, in Miltenova, A., Baranov, V. et al. (eds), Digital and Analytical Approaches to the Written Heritage, Gutenberg, Sofia, p. 114-128.

Knoll, V. (2019b). Lexicografia slavonă și slava veche și intrarea ei în era digitală, in "Studii și cercetări lingvistice”, 70 (1), p. $74-$ 87.

Knoll, V. (2021). The "Romanian Slavonic language“ and lexicography, in Janyšková, I., Karlíková, H., \& Boček, V. (eds), Old Church Slavonic Heritage in Slavonic and Other Languages, NLN, Prague, p. 307-323.

LLP = Kurz, J. \& Hauptová, Z. (eds) (1958-1997). Lexicon lingua paleslovenica - Slovnik jazyka staroslovènského, fasc. 1-52, 1958-1997, Academia, Prague; vol. I, 1966, vol. II, 1973, vol. III, 1982, vol. IV, 1997.

Mareš, F. V. (2000). Cyrilometodéjská tradice a slavistika, Torst, Prague.

Mathiesen, R. (1984). The Church Slavonic Language Question: An Overview (IX-XX Centuries), in Picchio R., Goldblatt, H. et al., Aspects of the Slavic Language Question I, Slavica Publishers, New Haven, p. 45-65.

Miklosich, F. (1862-1865). Lexicon paleslovenico-graco-latinum, Guilelmus Braumueller, Vindobonæ.

Moxa, M. (1620). De’ nceputul lumieei... [Cronică], in: Russian State Library, coll. 87, no. 64.

Olteanu, P. et al. (1975). Slava veche și slavona romănească, Editura didactică și pedagogică, București.

Pilát, Š. (2020). Elektronický slovnik jazyka staroslovénského - perspektivy dalšího vývoje, in "Bohemica Olomucensia. Linguistica“, p. 74-90.

Pilát, Š. et al. (2018). The Gorazd Project: An Old Church Slavonic Digital Hub, Academia, Prague, [online].

\footnotetext{
${ }^{23}$ Similarly as the Anglo-Norman Dictionary (which is a dictionary of an Old French variety) offers links to the Oxford English Dictionary, see anglo-norman.net.
} 
Rosenschon, U. (1994). Sechs Seiten medizinischer Rezepte im glagolitischen Psalter $3 / N$ des Sinaiklosters, in "Byzantinoslavica", LX (2), p. 304-335.

$\mathrm{SBR}=$ Ivanova-Mirčeva, Dora et al. (1999). Starobălgarski rečnik, tom 1-2, Valentin Trajanov, Sofia.

ssum = Humec'ka, L.L. et al. (1977-1978). Slovnyk staroukrajins'koji movy XIV-XV st. 1-2, Naukova dumka, Kiev.

Tolstoj, N.N. (1988). Istorija i struktura slavjanskich literaturnych jazykov, Nauka, Moscow. 